\title{
Of isbræ and ice streams
}

\author{
MARtin TRUFFER, Keith A. ECHELMEYER \\ Geophysical Institute, University of Alaska Fairbanks, 903 Koyukuk Drive, Fairbanks, AK 99775-7320, U.S.A. \\ E-mail:truffer@gi.alaska.edu
}

\begin{abstract}
Fast-flowing ice streams and outlet glaciers provide the major avenues for ice flow from past and present ice sheets. These ice streams move faster than the surrounding ice sheet by a factor of 100 or more. Several mechanisms for fast ice-stream flow have been identified, leading to a spectrum of different ice-stream types. In this paper we discuss the two end members of this spectrum, which we term the "ice-stream" type (represented by the Siple Coast ice streams in West Antarctica) and the "isbræ" type (represented by Jakobshavn Isbræ in Greenland). The typical ice stream is wide, relatively shallow $(\sim 1000 \mathrm{~m})$, has a low surface slope and driving stress $(\sim 10 \mathrm{kPa})$, and ice-stream location is not strongly controlled by bed topography. Fast flow is possible because the ice stream has a slippery bed, possibly underlain by weak, actively deforming sediments. The marginal shear zones are narrow and support most of the driving stress, and the ice deforms almost exclusively by transverse shear. The margins seem to be inherently unstable; they migrate, and there are plausible mechanisms for such ice streams to shut down. The isbræ type of ice stream is characterized by very high driving stresses, often exceeding $200 \mathrm{kPa}$. They flow through deep bedrock channels that are significantly deeper than the surrounding ice, and have steep surface slopes. Ice deformation includes vertical as well as lateral shear, and basal motion need not contribute significantly to the overall motion. The marginal shear zones tend to be wide relative to the isbræ width, and the location of isbræ and its margins is strongly controlled by bedrock topography. They are stable features, and can only shut down if the high ice flux cannot be supplied from the adjacent ice sheet. Isbræs occur in Greenland and East Antarctica, and possibly parts of Pine Island and Thwaites Glaciers, West Antarctica. In this paper, we compare and contrast the two types of ice streams, addressing questions such as ice deformation, basal motion, subglacial hydrology, seasonality of ice flow, and stability of the ice streams.
\end{abstract}

\section{INTRODUGTION}

Present-day ice sheets drain the largest part of their ice through ice streams and fast-flowing outlet glaciers. This was presumably true for some of the paleo-ice sheets as well (e.g. Brown and others, 1987; MacAyeal, 1993). Recent advances in remote-sensing techniques have revealed that ice streams are very widespread (e.g. Fahnestock and others, 2001; RADARSAT-1 Antarctic Mapping Project mission), and that some of the fast flow associated with known ice streams in West Antarctica affects a much larger part of the ice sheet and is much more far-reaching than previously thought (Joughin and others, 1999).

It has been recognized that ice streams show a variety of behaviors. Bentley (1987) pointed out the strikingly different flow mechanism of the Ross ice streams compared to other known ice streams and outlet glaciers. It has become clear that a range of ice-stream types exist, ranging from the shallow and soft-based to the ones flowing through deep channels. In this paper, we discuss examples of the two end members. We will use Whillans Ice Stream as the archetypical soft-bedded, shallow ice stream, on the one hand, and Jakobshavn Isbræ as the typical deep and steep isbræ. We will use a combination of data and modeling results to illustrate typical features, such as geometry and the flow, stress and temperature fields.

We also note there is a further type of ice stream, commonly termed an outlet glacier, which we define to be a glacier that drains an ice sheet through a bedrock channel in which the channel walls are exposed at the surface along much of the streaming part of the flow, as for instance Byrd, Leverett and Nimrod Glaciers (e.g. McIntyre, 1985).

\section{FIELD DATA}

\section{Whillans Ice Stream}

On the recently renamed Whillans Ice Stream (labeled WIS herein) we discuss data and model results at the UpB transect as being typical of this type of ice stream. Surface and bed topography were measured by Shabtaie and others (1987), and in local detail by Echelmeyer and Harrison (1999). The latter authors, plus Whillans and others (1993) and Echelmeyer and others (1994), measured detailed surface velocity profiles across much of the ice-stream width at this location. Temperature data are available for a total of six boreholes drilled in a transect from the ice sheet to the ice-stream center (Engelhardt and Kamb, 1993; Harrison and others, 1998; personal communication from $\mathrm{H}$. Engelhardt, 1994).

\section{Jakobshavn Isbræ}

Clarke and Echelmeyer (1996) used seismic methods to measure the bedrock topography of Jakobshavn Isbræ (JHI herein). Here we discuss observations along a transect about $50 \mathrm{~km}$ from the calving face, where a profile of surface 
velocity has been recorded (Clarke and Echelmeyer, 1996). Iken and others (1993) measured temperatures in three boreholes, two of which reached the glacier base. Lüthi and others (2002) measured deformation rates and temperatures in several boreholes in the adjacent ice sheet. The maximum ice thickness near the center of the transect is almost $2700 \mathrm{~m}$, and the surface slope is about $1.0^{\circ}$ (Echelmeyer and others, 1991).

\section{MODEL}

We used a finite-element (FE) model to calculate flow through these cross-sections. The model was constructed using a commercial package $\left(\right.$ Femlab $\left.^{\circledR}\right)$ adapted to solve the incompressibility and momentum equations for a power-law ice rheology, with stress exponent $n$ equal to 3 . We solve for all three velocity components in a transverse cross-section, but we do not allow out-of-plane gradients (a so-called 21/2dimensional model). The model has been tested against a number of analytical and previously calculated numerical solutions (Truffer, unpublished information), and was found to be very accurate and efficient.

The model inputs consist of the measured geometry and out-of-plane surface slope. The rate factor in the flow law was calculated at each point using interpolated temperatures within the cross-sections, with the Arrhenius temperature dependence given by Paterson (1994).

In the case of WIS, we followed Echelmeyer and others (1994) by introducing a laterally varying enhancement factor that is, in part, due to ice recrystallization under large strains. This enhancement factor was used to tune the model to match the observed surface velocities. The bed was kept frozen outside the ice stream (no basal slip there), and a constant basal shear stress of $3.5 \mathrm{kPa}$ was prescribed under the ice stream, based on the observations of Rooney and others (1987) and Kamb (1991), and the previous work of Echelmeyer and others (1994).

The JHI model also used fabric-induced enhancement, but in a basal layer. We specified an enhancement factor of 3 based on measurements at Dye 3 by Shoji and Langway (1988) and in situ borehole tilt measurements in the ice sheet next to our profile on JHI by Lüthi and others (in press), who attribute the softening to increased dust and impurity ice content in the near-bed pre-Holocene ice (Paterson, 1981). The thickness of this enhanced basal layer was taken to be $150 \mathrm{~m}$ at the side of the ice stream and $900 \mathrm{~m}$ in the center, based on these observations. We also assumed that much of the basal ice was temperate, based on the temperature measurements, and the inferred and measured large vertical stretching of the basal ice described by Iken and others (1993) and Lüthi and others (2002). The prescribed basal motion is based on measurements by Lüthi and others (2002) at the margin, and is chosen to reproduce measured surface velocities. The thickness of temperate and enhanced basal layers, and the amount of basal motion are not well restricted by observations. The model presented here is only one of many possible ones that reproduce current observations. The subsequent discussion does not rely heavily on the exact model, however.

Iken and others (1993) have pointed out the threedimensional nature of flow at JHI. The current model is not capable of addressing this adequately. This should be kept in

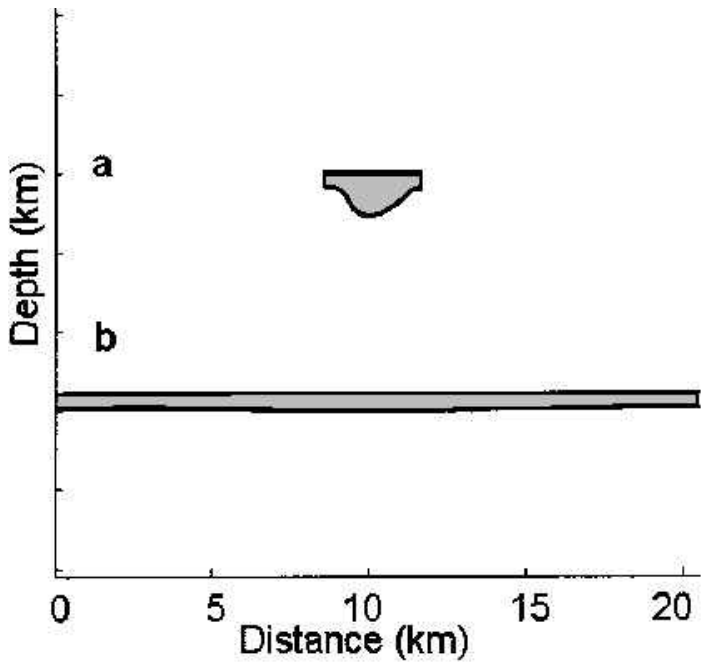

Fig. 1. Cross-sections of Jakobshavn Isbre (a) and Whillans Ice Stream ( $b$ ). The figure is plotted without vertical exaggeration, in order to better illustrate the difference between the two types.

mind in the following discussion. It will be less important for the more two-dimensional nature of flow at WIS.

\section{GEOMETRY}

Figure 1 shows the cross-sections of the two ice streams with no vertical exaggeration. This figure serves to illustrate the tremendous differences in geometry. WIS is shallow $(1000 \mathrm{~m})$, with little variation in ice thickness at this scale. The aspect ratio of the ice stream (width $(>30 \mathrm{~km})$ to depth $(1 \mathrm{~km}))$ seems to imply that, except close to the margins, the ice would not be affected by the margins were it not for the slipperiness of the bed. For comparison, JHI flows in a narrow, $2700 \mathrm{~m}$ deep trough (Clarke and Echelmeyer, 1996). JHI is much steeper (a slope of $18 \times 10^{-3}$ vs about $1.3 \times 10^{-3}$ for WIS). WIS has a driving stress of about $11 \mathrm{kPa}$, while that of JHI is about $208 \mathrm{kPa}$, assuming a parabolic shape factor of 0.5 .

An important difference between the two ice streams is the downslope increase in ice thickness at JHI. This does not occur at WIS. In this paper, we limit the discussion to flow through one cross-section.

\section{ICE MOTION}

Figure 2 shows contour plots of calculated out-of-plane velocities. The modeled surface velocities (solid curves) match measured values (symbols) closely, even in the marginal zones. The total flux through both ice streams at these locations is about $1 \times 10^{10} \mathrm{~m}^{3} \mathrm{a}^{-1}$, despite their vastly different geometries (Fig. 1). In this section, we discuss the different basal motion and internal ice deformation that give rise to the modeled fit to the observations. It should be noted that while not strictly unique, the conclusions regarding these two contributions are robust if the details of the velocity profiles are modeled closely.

\section{Basal motion}

The high velocities observed on WIS $\left(440 \mathrm{~m} \mathrm{a}^{-1}\right)$ at the low driving stress discussed above are only possible if the bed is 


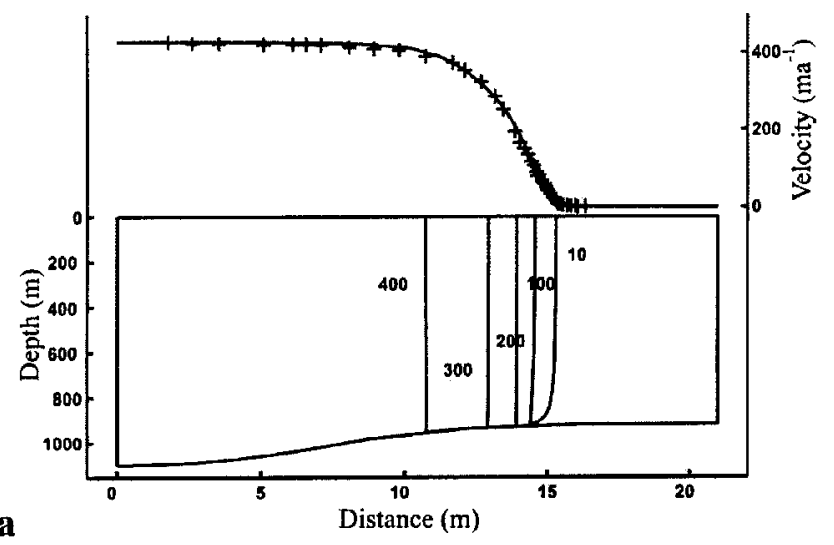

$\mathbf{a}$

Distance $(\mathrm{m})$

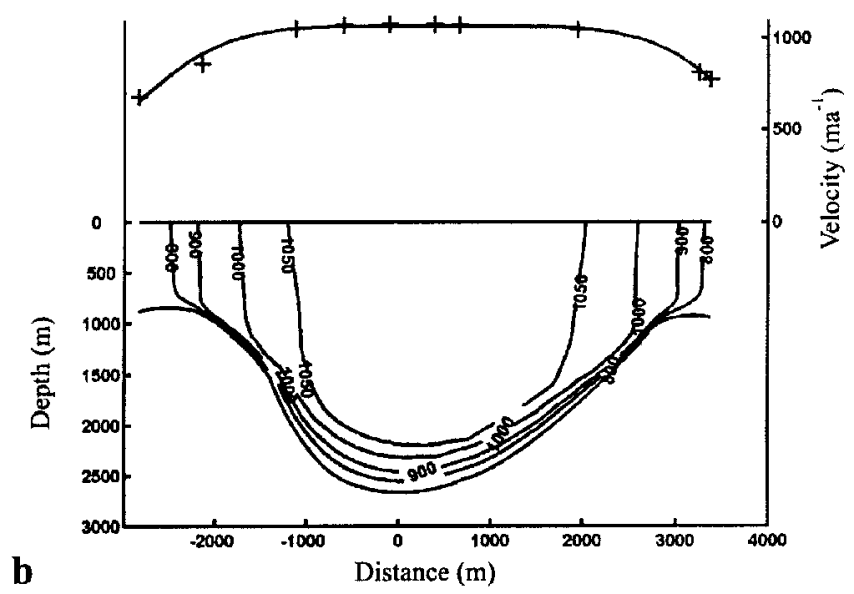

a
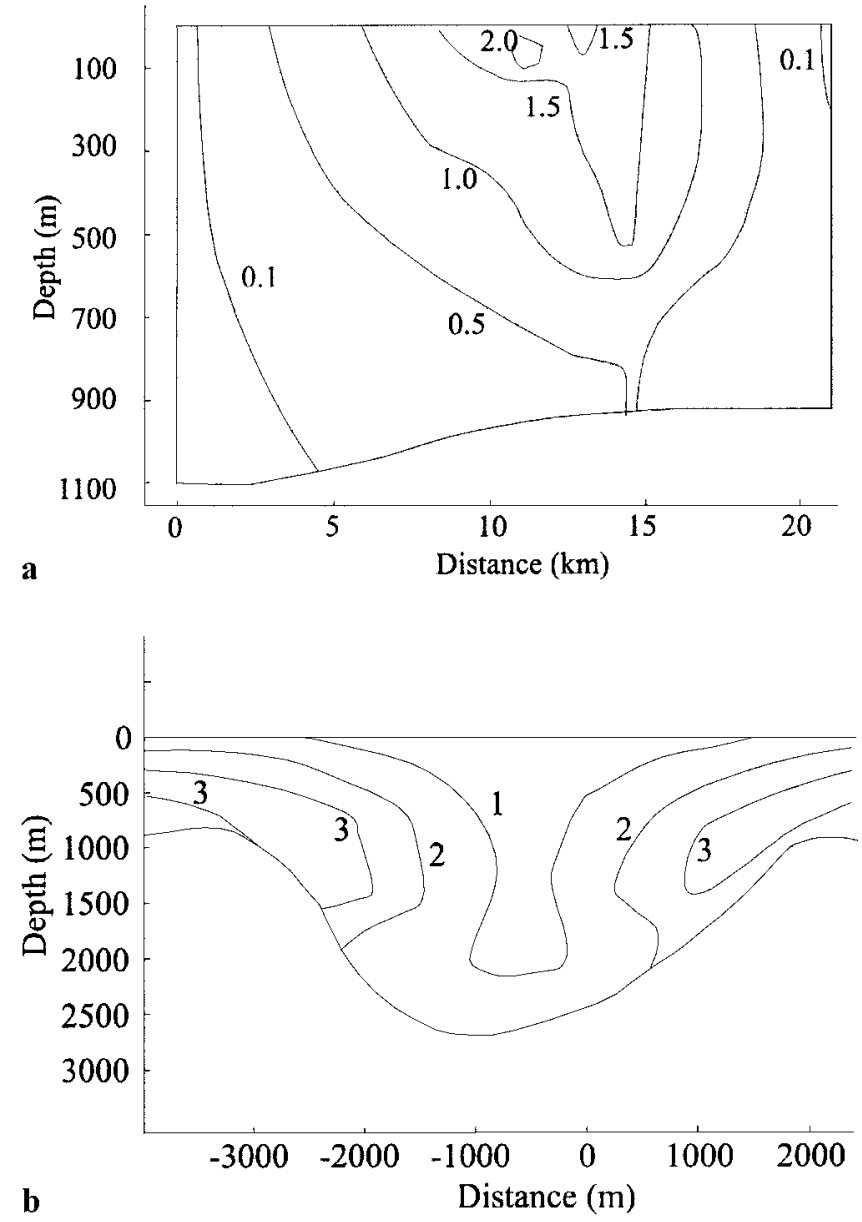

Fig. 2. (a) Velocity contours (in $m a^{-1}$ ) for WSI. Note the vertical exaggeration in this and other plots of WIS (cf. Fig. 1). This and subsequent plots of WIS only show one-half of the ice stream, with the ice-sheet side on the right. (b) Velocity contours $\left(\mathrm{ma}^{-1}\right)$ for FHI. Units on the axis are in meters.

very slippery. Our modeling suggests that basal motion is virtually $100 \%$ of the surface motion over most of the transverse section. Borehole observations by Engelhardt and Kamb (1998) inferred sliding between the basal ice and the underlying till of $83-100 \%$ of the surface motion, and there is some indication that the lower number is an artifact of the early measuring process. This is in stark contrast to JHI, where about $60 \%$ of the motion is basal motion. The exact amount of basal motion depends on the thickness of the enhanced layer, the amount of enhancement, and the thickness of the temperate layer, none of which are well constrained by observations.

\section{Ice deformation}

Ice deformation in WIS is almost exclusively by lateral shear (Fig. 2). This figure also shows a somewhat more complicated flow regime (lateral as well as vertical strain rates) in the marginal area where the transition from a frozen to a soft bed occurs. As ice traverses the shear margin, it is exposed to a large amount of accumulated strain, and alignment of the ice crystals and fabric softening should therefore occur (e.g. Jacka and Budd, 1989). Fabric-induced flow enhancement is indeed necessary in any flow model to match observed surface velocities, but estimates range from factors of 2-3 (Whillans and Van der Veen, 1997) to > 10 (Echelmeyer and others, 1994). The model we present here includes measured ice temperatures and measured topography, but

not longitudinal gradients. Fabric-induced flow enhancement that is even larger than that predicted by the models of Echelmeyer and others (1994) is required to match the observations. This is because the cold, stiff ice near the surface of the shear margin supports a larger amount of the driving stress than does the warmer (and softer) ice at depth.

The significant enhancement required by these flow models is robust with respect to any reasonable distribution of basal shear stress. But it must be noted that the range of estimates of the enhancement factor found by different studies is, to some extent, related to how well the details of the flow patterns are matched. If the observed near-margin shear strain rates and velocity profile are not fit as closely, then of course the required flow enhancement is less than the values we find here.

The slippery base of WIS makes its width $W$ of primary importance to its center-line velocity, $v$. A simple analysis predicts $v \propto W^{4}$ (Raymond, 1996), and leads to a possible instability if the ice stream expands laterally, while maintaining its water-saturated, slippery base.

Figure 3 shows modeled velocities of JHI. The ice deformation field is more complex than in the case of WIS and involves significant vertical as well as lateral shear. Flow patterns are determined by the existence of the bedrock trough in that they resemble the flow of a valley glacier with rock walls. High deformation rates occur in the temperate basal layer (Iken and others, 1993; Funk and others, 1994; Lüthi and others, 2002). The pre-Holocene basal ice layer (150-900 m thick) has been observed to be softer than 

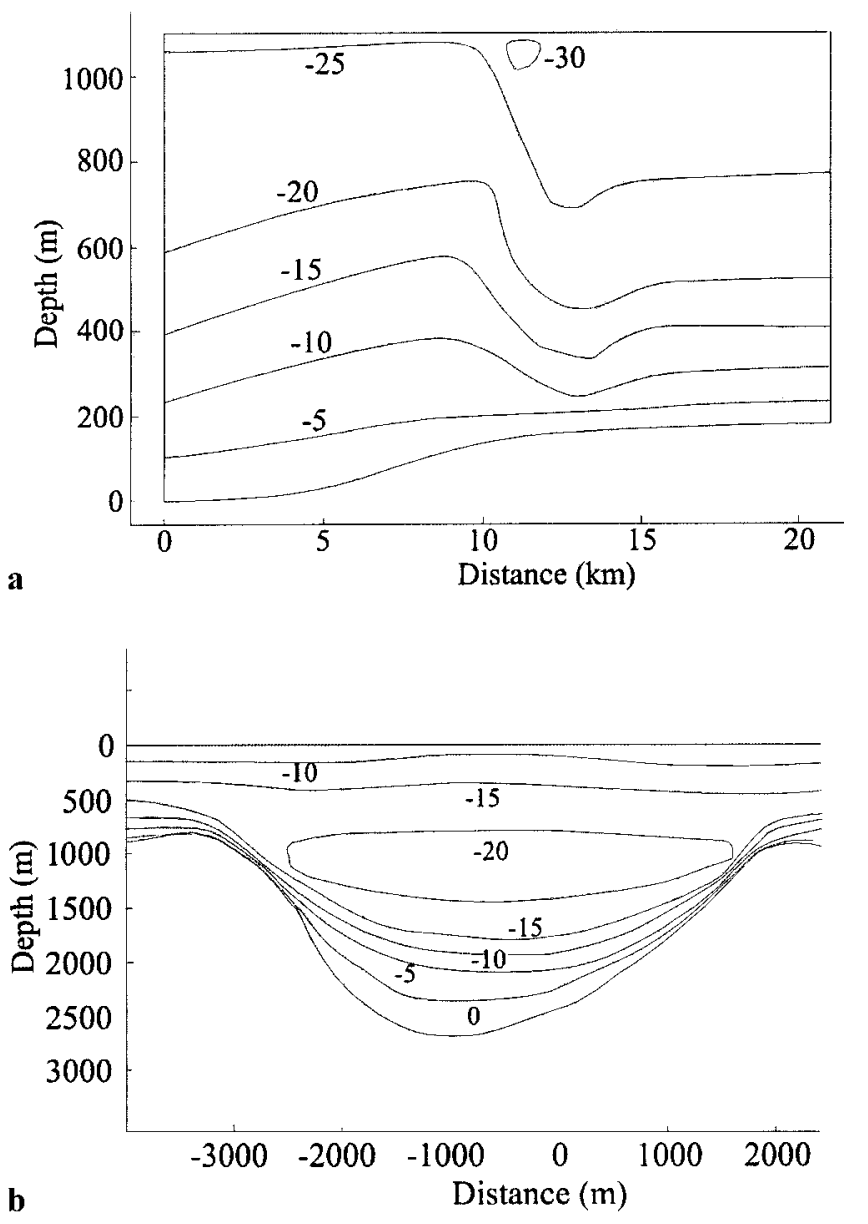

Fig. 4. Temperature contours $\left(\right.$ in $^{\circ} C$ ) for (a) WIS and ( $b$ )

7HI. Temperatures are relative to the local pressure-melting point and thus appear as $0^{\circ} \mathrm{C}$ for the temperate layer.

the overlying ice (Shoji and Langway, 1988; Paterson, 1991; Lüthi and others, 2002).

\section{STRESS DISTRIBUTION}

A large portion of the driving stress of WIS is supported by its margins. In our model we find that they support about twothirds of the total; other authors have suggested 50-100\% (Echelmeyer and others, 1994; Whillans and Van der Veen, 1997; Harrison and others, 1998). The depth variation of stress is not uniform (Fig. 3). Large shear stress concentrations (up to $200 \mathrm{kPa}$ ) occur in the upper layers of the marginal zones, where the ice is cold (Harrison and others, 1998) and stiff. This explains, to some extent, why other studies using observations mainly from within the upper third to half of the icestream thickness (Jackson and Kamb, 1997; Harrison and others, 1998) have found higher margin shear stresses, and thus infer a larger proportion of margin support.

The average basal shear stress of WIS is small, but nonzero. In this model we obtained a best fit to observed surface velocities with $3.5 \mathrm{kPa}$, close to the value of $5-6 \mathrm{kPa}$ found by Echelmeyer and others (1994). This value is higher than the measured shear strength of basal till samples $(\sim 2 \mathrm{kPa}$; Engelhardt and others, 1990; Kamb, 1991), which suggests that some distribution of "sticky spots" serves to increase the average basal shear stress. It is interesting to note that there is no way to match both the observed center-line velocity and the marginal strain rates if we impose a basal shear stress of $2 \mathrm{kPa}$ or less.

The shear stresses within the JHI cross-section exceed $300 \mathrm{kPa}$ at the flanks, and are $>200 \mathrm{kPa}$ in the temperate basal ice at the center of the channel (Figs 3 and 4). These stresses cause very large deformation rates, enabling the high flow velocities observed on the surface. The model produces a non-linear shear stress vs depth relation, contrary to the often-made assumption of linearity. This is in part due to the changes in ice temperature with depth and in part the geometry of the channel. Such a variation has also been predicted by models of temperate-valley glacier flow (Truffer and others, 2001).

\section{THERMAL REGIME}

The temperature field of WIS (Fig. 4) is influenced to some degree by the passage of ice through the shear margins into the ice stream. Two effects are important: first, strain heating due to large deformation rates and shear stresses and, second, chilling by cold air pooling in surface crevasses over winter. Harrison and others (1998) discussed both these effects, and used them to estimate shear stress in the upper third of the margin (200 kPa; cf. Fig. 3), and the current margin migration rate.

Even though basal velocities are high, the low basal shear stresses lead to minimal strain heating at the base of the ice stream. Most of the gravitational energy of the moving ice is dissipated in the margins, where the ice is generally cold (except near the bed; Raymond, 2001). Ice at the base of WIS is at the melting point, but no temperate layer is present. The geothermal heat flux is on the same order as the conductive heat flux into the ice. This means that small changes could lead to a switch between a melt and a freezeon condition at the ice-stream base, providing a mechanism for ice-stream slow-down, or even shut-down (Tulaczyk and others, 2000).

The coldest ice of JHI is found at a depth of about half the center-line maximum (1300 m; Fig. 4). This ice has been advected from upstream, where the ice is colder. The high stresses and deformation rates create enough strain heating to maintain a significant basal layer of temperate ice (Funk and others, 1994). In contrast to the situation at WIS, strain energy dissipation occurs mainly within the temperate ice, and it is therefore used to produce melt. The inferred basal melt rate beneath JHI is about $0.5 \mathrm{~m} \mathrm{a}^{-1}$.

\section{GEOMETRY OF THE LATERAL SHEAR ZONES}

Distinct marginal shear zones are prominent features of most ice streams (e.g. Raymond, 1996; Raymond and others, 2001), delineating the faster-moving parts of both ice-stream types in satellite images and air photos. These zones are characterized by an abrupt transition from icesheet to ice-stream flow, with the associated large strain rates and intense crevassing. Visual observations, as well as measured and modeled velocity patterns, indicate that some of these characteristics are different for Siple Coast-type ice streams and isbræs.

The different patterns of strain rate across the two representative ice streams are clearly illustrated by a comparison of transverse strain rates on a normalized horizontal scale (Fig. 5). Four differences are of note. First, because the over- 
all surface velocity is much larger on JHI than on WIS, the strain rates are also larger there, by a factor of more than two in this case. This is somewhat surprising in that one of the often-quoted "signatures" of the Ross ice streams has been the high lateral strain rates. We do note that this difference in strain-rate magnitude may vary down the length of different ice streams of each type. This is because the difference between the typical ice-stream velocity and that of the surrounding ice sheet increases in the downstream direction, and the width of the shear margins also changes, as discussed next.

The second difference between the two types of margins is their relative width. The zone of high shear rates is much larger relative to the ice-stream width on JHI than on WIS. In our example, the shear margin on JHI represents nearly half of the overall isbræ width, while on WIS it is only about $20 \%$ of the total ice-stream width. This difference results from the underlying patterns of shear stress magnitude (Fig. 3). Ice deformation over much of the JHI section is strongly affected by the walls of the subglacial channel, while the ice in most of the WIS section does not directly "feel" the resistance offered by the ice outboard of the margin, and the zones of high strain rate are more localized.

The third difference is in the nature of the crevassing in the marginal zones, which is a direct consequence of the different stress and strain-rate fields. In the WIS margins, such as the "Dragon" and the "Snake", the crevassing appears to be chaotic within a narrow zone, with large, arcuate crevasses on either side of the chaotic zone. On the other hand, the shear zones of JHI have a broad zone of less chaotic, but large crevasses. Below the grounding line, JHI surface crevassing becomes as chaotic as that typical of WIS, and the crevassing appears to be that typical of fast-moving tidewater glaciers.

A fourth difference is the relatively large influx of ice through the margins at JHI (not represented in the model). This leads to an advection of crevasses towards the ice-stream center. On the other hand, at WIS crevasses are continuously rotated in the flow field and recreated, leading to a much more chaotic crevasse zone.

It is likely that these differences in shear margin can be used to identify the type of ice stream using satellite imagery. And, because the marginal structure is linked to the bedrock topography, the characteristics of the margins may indicate presence or absence of a bedrock channel, and of the underlying flow mechanisms.

\section{BASAL HYDROLOGY AND SEASONAL VELOGITY FLUGTUATIONS}

Basal melting and surface melting are minimal on WIS. In contrast, surface melting is strong on the lower $80 \mathrm{~km}$ of JHI during summer (Echelmeyer and others, 1991) and there is significant basal melting, as mentioned above. The high basal melt rates at JHI will affect the basal hydraulic system. A lack of seasonality in these melt rates might explain the lack of seasonality in isbræ speeds (Echelmeyer and Harrison, 1990). On the ice sheet adjacent to the isbræ, seasonality in velocity has been observed (Lüthi and others, 2002). We hypothesize that the high basal melt rates of the isbræ maintain an efficient drainage system that leads to low basal water pressures, little basal motion and little seasonality in ice velocity there, even with the strong seasonal surface water influx. In this context, it is interesting to note that temperate

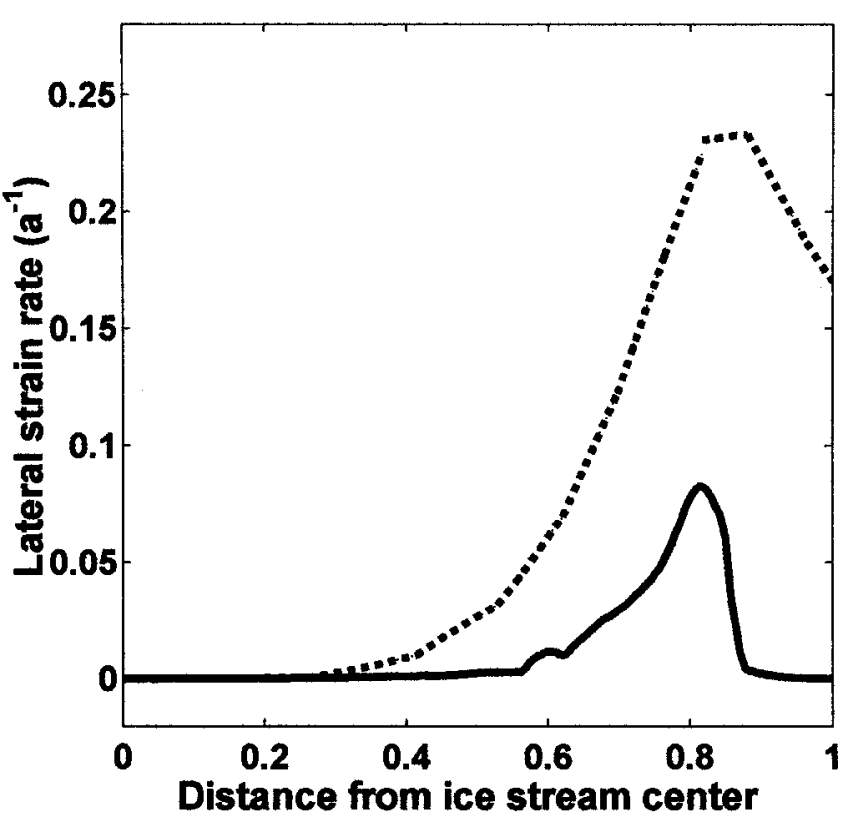

Fig. 5. Transverse strain rates ( $a^{-1}$ ) across the two ice streams. The horizontal axis is the distance across the ice stream normalized by the half-width at this location $(18 \mathrm{~km}$ on WIS (solid line) and $4.5 \mathrm{~km}$ on $\mathcal{F H I}$ (dotted line)).

LeConte Glacier, southeast Alaska, U.S.A., which flows at velocities and under basal shear stresses similar to those at JHI, also shows little seasonality in its velocities (O'Neel and others, 2001). This is unusual for temperate glaciers (e.g. Willis, 1995), but could be explained by a well-maintained drainage system due to high basal melt rates.

\section{STABILITY}

It has been shown that the Siple Coast ice streams are not steady features (e.g. Fahnestock and others, 2000). Ice Stream G shut down about 150 years ago (Rose, 1979), and the margins of WIS have been shown to migrate (e.g. Bindschadler and Vornberger, 1998; Echelmeyer and Harrison, 1999). The simplified model of Jacobsen and Raymond (1998) has shown that ice-stream margins cannot be steadystate features because strain heating at the margins warms up the outboard ice and thus expands the thawed bed zone. A widening of the margins should lead to a speeding-up of the ice stream if basal friction is negligible. Yet Echelmeyer and Harrison (1999) observed slowing of WIS, at the same time that one margin was migrating outward. This indicates a simultaneous change in resistive drag at the base of the ice stream if the opposite margin is stationary or also migrating outward. Tulaczyk and others (2000) proposed that freeze-on processes at the base of an ice stream could draw water from a basal till layer and increase the shear strength of the subglacial till. This could slow down or even shut down the ice stream if it is widening too quickly.

On the other hand, the dynamics of JHI do not offer any mechanisms that would make it unstable. It is well constrained by bedrock topography, with strain heating concentrated at the base rather than the margins. This reduces the potential for margin migration. Changes should therefore only be expected on longer time-scales, through either further erosion of the bedrock channel, exhaustion of the ice supply necessary to maintain fast motion, or changes in calving. 


\section{GLASSIFIGATION OF IGE STREAMS}

The two extremes of fast-flowing ice streams presented here should be regarded as the end members in a continuum of ice-streaming behavior. In Table 1 we list several ice streams in Greenland and Antarctica. Using available information on width, slope, depth, speed and the nature of the shear margins, we have categorized them into probable icestream types. This characterization may be used to infer bedrock topography — deep channel or not - where such information is not yet available, and to give some insight into the relevant flow mechanisms.

This survey shows that the Siple Coast-type ice streams are more limited in number than mixed or isbræ types. This implies that both isbræ-type and Siple Coast-type physics will be important for understanding such regions as the Pine Island-Thwaites drainage basin and possibly the large ice stream draining northeast Greenland. It also implies that ice-sheet stability questions require incorporation of these diverse ice-stream dynamics.

\section{GONGLUSIONS}

We have characterized ice-stream behavior by defining two end members of a spectrum: the Siple Coast "ice stream" and the Jakobshavn "isbræ". The ice streams involve slippery beds, low driving stresses, and significant support by the margins, while isbræs involve significant internal ice deformation, have high driving stresses, and are strongly affected by basal as well as lateral drag. The surface expression of these two types is readily apparent: typically wide shear margins on isbræs and narrow ones on ice streams. These visual differences can possibly be used to infer underlying flow mechanisms and bedrock topography. The nature of paleo-ice streams can also be inferred using information on such factors as bedrock topography and the presence of till, as has been done previously by, for instance, Brown and others (1987).

These results show that questions of ice-sheet stability will require an understanding of both types of ice streams, as they both appear to drain significant portions of both past and present ice sheets. They also show that the dynamics of the two types are quite different. This poses unique challenges to researchers modeling complex areas, where both types of flow occur in the same ice stream, such as Pine Island Glacier.

\section{AGKNOWLEDGEMENTS}

This work was supported by U.S. National Science Foundation grant OPP-0086997. We thank S. Marshall, C. Hulbe and M. Funk for helpful comments.

\section{REFERENGES}

Bentley, C. R. 1987. Antarctic ice streams: a review. 7. Geophys. Res., 92(B9), 8843-8858.

Bindschadler, R. and P. Vornberger. 1998. Changes in the West Antarctic ice sheet since 1963 from declassified satellite photography. Science, 279(5351), 689-692.

Brown, N. E., B. Hallet and D. B. Booth. 1987. Rapid soft bed sliding of the Puget glacial lobe. F. Geophys. Res., 92(B9), 8985-8997.

Clarke, T. S. and K. Echelmeyer. 1996. Seismic-reflection evidence for a deep subglacial trough beneath Jakobshavns Isbræ, West Greenland. 7 . Glaciol., 42(141), 219-232.
Table 1. Arrow going down represents the transition from icestream type to isbre type. The following abbreviations are used:WA, West Antartica; EA, East Antarctica; G, Greenland; L, Laurentide/Cordilleran paleo-ice sheet

Whillans Ice Stream (WA)

Ice Streams D andE (WA)

Ice Stream C (WA)

Puget lobe (L)

Wisconsin lobes (L)

Ice Stream A (WA)

Recovery (EA)

Rutford Ice (WA)

Evans (WA)

Pine Island (WA)

Thwaites (WA)

Northeast Greenland Ice Stream $(G)$

Foundation (EA/WA)

Nioghalvfjerdsbræ $(\mathrm{G})$

Slessor (EA)

Lambert (EA)

Denman (EA)

Totten (EA)

Merz (EA)

Shirase $(\mathrm{EA})$

Vanderford (EA)

Rennick (EA)

Petermann $(\mathbf{G})$

Jutulstraumen(EA)

Hudson Strait (L)

Kangerlussuaq $(\mathrm{G})$

Rink Gletscher, Rink Isbræ $(\mathrm{G})$

Upernavik Isstrøm $(\mathrm{G})$

Jakobshavn $(\mathrm{G})$

Ice stream

Amundsen, Beardmore, Byrd, Leverett, Nimrod, Scott, Shackleton, Skelton... (EA) - outlet glaciers

Notes: Data and images from various sources, including McIntyre (1985), Bentley (1987) and Swithinbank (1988).

Echelmeyer, K. and W. D. Harrison. 1990. Jakobshavns Isbræ, West Greenland: seasonal variations in velocity - or lack thereof. F. Glaciol., 36(122), 82-88.

Echelmeyer, K. A. and W. D. Harrison. 1999. Ongoing margin migration of Ice Stream B, Antarctica. 7. Glaciol., 45(150), 361-369.

Echelmeyer, K., T. S. Clarke and W. D. Harrison. 1991. Surficial glaciology of Jakobshavns Isbræ, West Greenland: Part I. Surface morphology. $\mathcal{F}$. Glaciol., 37(127), 368-382.

Echelmeyer, K. A., W. D. Harrison, C. Larsen and J. E. Mitchell. 1994. The role of the margins in the dynamics of an active ice stream. F. Glaciol., 40(136), 527-538.

Engelhardt, H. and B. Kamb. 1993. Vertical temperature profile of Ice Stream B. Antarct. J. U.S., 28(5), Review 1993, 63-66.

Engelhardt, H. and B. Kamb. 1998. Basal sliding of Ice Stream B, West Antarctica. F. Glaciol., 44(147), 223-230.

Engelhardt, H., N. Humphrey, B. Kamb and M. Fahnestock. 1990. Physical conditions at the base of a fast moving Antarctic ice stream. Science, 248(4951), 57-59.

Fahnestock, M. A., T. A. Scambos, R. A. Bindschadler and G. Kvaran. 2000. A millennium of variable ice flow recorded by the Ross Ice Shelf, Antarctica. 7. Glaciol., 46(155), 652-664.

Fahnestock, M., W. Abdalati, I. Joughin, J. Brozena and P. Gogineni. 2001. High geothermal heat flow, basal melt, and the origin of rapid ice flow in central Greenland. Science, 294(5550), 2338-2342.

Funk, M., K. Echelmeyer and A. Iken. 1994. Mechanisms of fast flow in Jakobshavns Isbræ, West Greenland: Part II. Modeling of englacial temperatures. F. Glaciol., 40(136), 569-585.

Harrison, W. D., K. A. Echelmeyer and C. F. Larsen. 1998. Measurement of temperature in a margin of Ice Stream B, Antarctica: implications for margin migration and lateral drag. 7. Glaciol., 44(148), 615-624.

Iken, A., K. Echelmeyer, W. Harrison and M. Funk. 1993. Mechanisms of fast flow in Jakobshavns Isbræ, West Greenland: Part I. Measurements of temperature and water level in deep boreholes. F. Glaciol., 39(131), 15-25. 
Jacka, T. H. and W.F. Budd. 1989. Isotropic and anisotropic flow relations for ice dynamics. Ann. Glaciol., 12, 81-84.

Jackson, M. and B. Kamb. 1997. The marginal shear stress of Ice Stream B, West Antarctica. 7. Glaciol., 43(145), 415-426.

Jacobson, H. P. and C. F. Raymond. 1998. Thermal effects on the location of ice stream margins. F. Geophys. Res., 103(B6), 12,111-12,122.

Joughin, I. and 7 others. 1999. Tributaries of West Antarctic ice streams revealed by RADARSAT interferometry. Science, 286(5438), 283-286.

Kamb, B. 1991. Rheological nonlinearity and flow instability in the deforming bed mechanism of ice stream motion. 7. Geophys. Res., 96(B10), $16,585-16,595$.

Lüthi, M., M. Funk, A. Iken, S. Gogineni and M. Truffer. 2002. Mechanisms of fast flow in Jakobshavn Isbræ, West Greenland. Part III. Measurements of ice deformation, temperature and cross-borehole conductivity in boreholes to the bedrock. F. Glaciol., 48(162), 369-385.

MacAyeal, D. R. 1993. Binge/purge oscillations of the Laurentide ice sheet as a cause of the North Atlantic's Heinrich events. Paleoceanography, 8(6), $775-784$.

McIntyre, N. F. 1985. The dynamics of ice-sheet outlets. F. Glaciol., 31(108), 99-107.

O'Neel, S., K. A. Echelmeyer and R. J. Motyka. 2001. Short-term flow dynamics of a retreating tidewater glacier: LeConte Glacier, Alaska, U.S.A. 7. Glaciol., 47(159), 567-578.

Paterson, W. S. B. 1991. Why ice-age ice is sometimes "soft". Cold Reg. Sci. Technol., 20(1), 75-98.

Paterson, W. S. B. 1994. The physics of glaciers. Third edition. Oxford, etc., Elsevier.

Raymond, C. 1996. Shear margins in glaciers and ice sheets. F. Glaciol., 42(140), 90-102.
Raymond, C. F. 2001. Energy balance of ice streams. 7. Glaciol., 46(155), 665-674 Raymond, C. F., K. A. Echelmeyer, I. M. Whillans and C. S. M. Doake. 2001. Ice stream shear margins. In Alley, R. B. and R. A. Bindschadler eds. The West Antarctic ice sheet: behavior and environment. Washington, DC, American Geophysical Union, 137-155. (Antarctic Research Series 77.)

Rooney, S.T., D. D. Blankenship, R. B. Alley and C. R. Bentley. 1987. Till beneath Ice Stream B. 2. Structure and continuity. 7. Geophys. Res., 92(B9), 8913-8920.

Rose, K. E. 1979. Characteristics of ice flow in Marie Byrd Land, Antarctica. 7. Glaciol., 24 (90), 63-75.

Shabtaie, S., I. M. Whillans and C. R. Bentley. 1987. The morphology of Ice Streams A, B, and C, West Antarctica, and their environs. 7. Geophys. Res., 92(B9), 8865-8883.

Shoji, H. and C. C. Langway, Jr. 1988. Flow-law parameters of the Dye 3, Greenland, deep ice core. Ann. Glaciol., 10, 146-150.

Swithinbank, C. 1988. Antarctica. U.S. Geol. Surv. Prof. Pap. 1386-B, B1-B138.

Truffer, M., K. A. Echelmeyer and W. D. Harrison. 2001. Implications of till deformation on glacier dynamics. F. Glaciol., 47(156), 123-134.

Tulaczyk, S. M., B. Kamb and H. F. Engelhardt. 2000. Basal mechanics of Ice Stream B, West Antarctica. II. Undrained-plastic-bed model. f. Geophys. Res., 105(B1), 483-494.

Whillans, I. M. and C. J. van der Veen. 1997. The role of lateral drag in the dynamics of Ice Stream B, Antarctica. F. Glaciol., 43(144), 231-237.

Whillans, I. M., M. Jackson and Y.-H. Tseng. 1993. Velocity pattern in a transect across Ice Stream B, Antarctica. f. Glaciol., 39(133), 562-572.

Willis, I. G. 1995. Intra-annual variations in glacier motion: a review. Prog. Phys. Geogr., 19(1), 61-106. 